\title{
Motivational Regulators of Migration Behavior of the Population
}

\author{
MARYNA SEMYKINA ${ }^{1}$, VIKTORIIA KABAI ${ }^{2}$, SVITLANA LUCHYK ${ }^{3}$, ANNA SEMYKINA ${ }^{4}$ \\ ${ }^{1}$ Department of Economy and Entrepreneurship Central UKRAINIAN NATIONAL TECHNICAL UNIVERSITY, \\ UKRAINE, E-mail: SemikinaMV@i.ua \\ ${ }^{2}$ Department of Economy and Entrepreneurship Central UKRAINIAN NATIONAL TECHNICAL UNIVERSITY, \\ UKRAINE, E-mail: kabai.vo@gmail.com \\ ${ }^{3}$ Department of Accounting and Taxation, CHERNIVTSI INSTITUTE OF TRADE AND ECONOMICS OF KYIV \\ NATIONAL UNIVERSITY OF TRADE AND ECONOMICS, Ukraine, E-mail: luchiksvitlana@gmail.com \\ ${ }^{4}$ Department of Personnel Management and Labor Economics ODESSA NATIONAL UNIVERSITY OF ECONOMICS, \\ UKRAINE, E-mail: a.semikina@gmail.com
}

\begin{abstract}
The article explores migration behavior of the population as an object of motivational influence and regulation. The basic types of mechanism for the regulation of migration behavior of the population are determined. The motivational mechanism of regulating the migration behavior of the population with the settlement of ideological and instrumental blocks is presented. The main tools for regulating the migration behavior of the population are identified. In terms of pointing out the intentions of migration, it is improving the competitive conditions of Ukrainian labor market using a financial and economic wage regulator. Due to the practice of migration - it is social protection of migrants through the application of the regulatory legal framework for the conclusion of interstate agreements and control over the observance of their provisions. Due to the consequences of displacement - it is promoting the effective use of migrants 'cash income through re-emigration programs, tax, investment and credit regulators (support for former migrants' businesses and their employment.
\end{abstract}

Keywords: Labor migration, Migration behavior, Motivation, Regulation, Mechanism, Tools

JEL Classification: J22, F22, O15 


\title{
Reguladores Motivacionales del Comportamiento Migratorio de la población
}

\author{
MARYNA SEMYKINA ${ }^{1}$, VIKTORIIA KABAI ${ }^{2}$, SVITLANA LUCHYK ${ }^{3}$, ANNA SEMYKINA ${ }^{4}$ \\ ${ }^{1}$ Department of Economy and Entrepreneurship Central UKRAINIAN NATIONAL TECHNICAL UNIVERSITY, \\ UKRAINE, E-mail: SemikinaMV@i.ua \\ ${ }^{2}$ Department of Economy and Entrepreneurship Central UKRAINIAN NATIONAL TECHNICAL UNIVERSITY, \\ UKRAINE, E-mail: kabai.vo@gmail.com \\ ${ }^{3}$ Department of Accounting and Taxation, CHERNIVTSI INSTITUTE OF TRADE AND ECONOMICS OF KYIV \\ NATIONAL UNIVERSITY OF TRADE AND ECONOMICS, Ukraine, E-mail: luchiksvitlana@gmail.com \\ ${ }^{4}$ Department of Personnel Management and Labor Economics ODESSA NATIONAL UNIVERSITY OF ECONOMICS, \\ UKRAINE, E-mail: a.semikina@gmail.com
}

\begin{abstract}
RESUMEN
El artículo explora el comportamiento migratorio de la población como objeto de influencia y regulación motivacional. Se determinan los tipos básicos de mecanismos de regulación del comportamiento migratorio de la población. Se presenta el mecanismo motivacional de regulación del comportamiento migratorio de la población con el asentamiento de bloques ideológicos e instrumentales. Se identifican los principales instrumentos de regulación del comportamiento migratorio de la población. En cuanto a señalar las intenciones de la migración, es mejorar las condiciones competitivas del mercado laboral ucraniano utilizando un regulador salarial financiero y económico. Debido a la práctica de la migración - es la protección social de los migrantes mediante la aplicación del marco jurídico regulador para la celebración de acuerdos interestatales y el control del cumplimiento de sus disposiciones. Debido a las consecuencias del desplazamiento - es la promoción del uso efectivo de los ingresos en efectivo de los migrantes a través de programas de reemigración, reguladores fiscales, de inversión y de crédito (apoyo a las empresas de los antiguos migrantes y su empleo.
\end{abstract}

Palabras claves: Migración laboral, Comportamiento migratorio, Motivación, Regulación, Mecanismo, Herramientas

Clasificación JEL: J22, F22, 015 


\section{Introduction}

Migration today has become a global phenomenon of increasing scale and complexity. The dynamics of labor migration can significantly affect the socio-economic situation in countries of origin, transit or destination of migrants. For Ukraine, this problem becomes especially relevant at the stage of European integration, when the nature and volume of migration processes have changed. The motives for the movement of migrant workers inside the country and abroad are primarily due to the lack of jobs, especially with decent pay and working conditions, risks of poverty even for working people, low level of social guarantees. The prospects of better earnings and support for families through external labor migration carry both significant positive opportunities and threats, in particular related to the outflow of economically active population from Ukraine. There is an urgent need to develop an adequate motivational mechanism to regulate the migration behavior of the population aimed at realizing the interests of the state and its population.

\section{Literature review}

Migration behavior is a type of demographic behavior and involves a set of actions and attitudes related to spatial displacement. Under the influence of the prospects of changing certain living conditions, there are attitudes towards migration behavior.

The migration behavior of the individual is affected by motivation as a process of the migration motive formation. The latter involves an awareness of the needs, interests, abilities, definition and implementation of the action plan respectively and the outcome (full satisfaction, partial satisfaction or dissatisfaction) (Alghamdi 2016). Depending on the degree of satisfaction of the need, the migration motive ceases to exist or becomes a migration installation (delayed intention to migrate until favorable conditions emerge).

The emergence of migratory attitudes, migration motives and the degree of activation of migration behavior of the able-bodied population is the result of the manifestation and interaction of a variety of motivational factors. They include economic, social-demographic, organizational-political, military, environmental, religious, natural and climatic, historical and ethnical, and mental. All these features at various levels have a multifaceted effect on labor choices of the population, making the desire to move to regions (countries) where there are incentives that are more attractive and opportunities.

The study of world experience has shown that the motivational factors of the migration process have verified historically and significantly in different countries, which necessitates the search for acceptable methods of regulation of labor migration, taking into account regional peculiarities, and specific situation. Depending on national needs, different methods of stimulating or restricting labor migration have been applied at different times in the same country (shaikh 2020). There are various reasons for motivating factors for each migrant, although the dominant role remains economic. Due to the threat of large-scale unregulated flows of migrant workers, governments are developing a migration policy to protect the national labor market. Since migration behavior is manifested at three levels (individual, group (family) and state), it is appropriate to create effective mechanisms for regulating labor migration at these levels.

The problems of motivation for labor migration and its regulation have been covered in various aspects by M. Biel (2017), A. Grishnova (2017), A. Kolot (2014), E. Libanova (2018), O. Malinovska (2011, 2018), and I. Petrova (2012), O. Ryndzak (2016, 2018), V. Sadova (2009), V. Sarioglo (2019), N. Tindyk (2009) and other Ukrainian researchers.

Taking into consideration the achievements of domestic and foreign scientists, it should be acknowledged that the motivation for labor migration of the population is still a poorly researched process. The scientific perceptions of the driving forces that force the able-bodied population to migrate, causing their superficial understanding and hindering the improvement of the motivational mechanism for regulating the migration behavior of the population, remain debatable. 


\section{Data and methodology}

The solution of the above-mentioned tasks is based on the use of general scientific and special methods of research, namely: systematic approach and an abstract-logical method (in order to identify and systematize motivational factors of migration behavior of the population). Economic, statistical and graphical analysis, synthesis (in order to determine the structure and features of functioning of the motivational mechanism of regulation migration behavior of population) is also applied. The method of analogies and comparative comparisons (in order to determine measures of influence on the labor market process).

The main information materials of the study were the legislative and regulatory acts of Ukraine, the materials of the State Statistics Service of Ukraine, the State Migration Service of Ukraine, the International Labor Organization, the results of expert assessments.

\section{Results}

Regulation of the motivation for labor migration of the population as an extremely difficult process necessitates the use of an appropriate mechanism. The motivational mechanism of regulating the migration behavior of the population is a holistic management system, whose action is aimed at changing (forming, adjusting, leveling) the motives of the population to move a certain distance, time and for a specific purpose. Unlike the incentive mechanism, the motivational mechanism must exert influence on internal motives with simultaneous external stimuli, the action of which would allow indirect ways to influence the migration behavior of the population.

The purpose of the motivational mechanism for regulating the migration behavior of the population is to ensure the positive impact of migration processes at the level of a particular individual, society, state, which are manifested in economic, social, political and security contexts and wholly ensure the quality of human development. The stated purpose is quite general. The idea should be consistent with the overall concept of the country's migration policy.

Based on the estimated results of the effects of migration, we substantiate the objectives and functionality of the motivational mechanism.

The tasks of a motivational mechanism are holistic guidelines for the use of regulatory methods and instruments that ensure the achievement of the stated goal. For different countries / regions, the tasks of the motivation mechanism may vary, but in the general ideology, they should be limited to the following:

1) regulation of the migration behavior of the population based on the assessment of factors of formation of needs, interests, motives of displacement;

2) improvement of the living environment in order to correct the motives of population migration (as a rule, decrease), stimulate the return of migrants and attract human (labor) potential from other countries / regions;

3) regulating the practice of displacement in compliance with the requirements of social protection, decent work and pay, and other human rights;

4) regulation of the consequences of migration (transformation of motives to meet the needs) in economic, social, political and security contexts, which must fully ensure the quality of human development.

All tasks are very closely interconnected, especially the first and the second. Their achievement is possible provided they understand the basic motives (economic, social, political, military, and environmental) that make the migration behavior of the population and those who encourage this moving.

Functionality of the motivational mechanism of migration behavior regulation of the population is as follows:

planning function: determination of migration intentions based on needs, interests, motives; 
function of analysis: research of migration behavior of the population based on the formation of needs, interests, motives; opportunities of formation, realization and development of abilities (potential) of a person in the country / regions of current residence;

regulation function: formation, adjustment and leveling of motives of movement - depending on the migration situation and its consequences at the level of a particular person, society, state;

control function: assessing the impact of migration on the quality of human development.

In order the motivational mechanism of regulating the migration behavior of the population to ensure the fulfillment of the set goals, objectives and functionality, its action must be performed in accordance with a number of principles. Thus, from the point of view of the regulation of migration behavior of the population, these principles are the following: consistency (of the interests of individuals, society and the state); legal certainty (strict compliance with legal norms); strategic (with a long-term orientation); indirect action (primary impact on motives, not migration practices); prevention (prevention of the negative effects of migration), science (justification of the mechanisms), innovation (orientation to the progressive changes in the growth of mobility, speed and comfort of movement).

The purpose, tasks, principles and functions determine the ideological block of the motivational mechanism. That is, they lay down the general idea of regulating the environment of the formation of migration motives, its practices and consequences with reflection on the quality of human development, taking into account the rational-conscious and mental-psychological aspects of life of society (Ostapenko, 2010)

Applied aspects of the motivation mechanism reveal the elements of the toolbox. Their application is carried out with the direct involvement of the regulatory entities that form the institutional support of the mechanism. The subjects of regulation of migration behavior of the population may be as the following:

authoritative: government and civil society institutions of receiving countries / regions and donor countries / regions;

market: subjects of the market of migration services (employers, intermediaries), competition (demand, supply), labor price.

In the sphere of migration regulation in general and migration behavior of the population, in particular, the role of the state should remain leading, despite the fact that the mechanism of public administration plays the role of the mechanism of social self-government.

In the course of influence of institutions of migration behavior regulation of the population, the migration policy is formed and implemented. The peculiarity of migration policy in terms of regulating the migration behavior of the population is its preventive nature (compliance with one of the principles of the motivational mechanism). Preventive policy implies its primary impact on the factors of migration with the creation of a favorable social and labor sphere (employment opportunities, wages) to prevent the mass departure of citizens abroad (Haisal, 2018). The implementation of preventive migration policy is possible if the migration processes are consistently and objectively regulated. For Ukraine, the preventive nature of regulatory measures is a difficult task, as currently the migration situation is not actually under the control of the state, giving way to the influence of market factors. Due to this, social standards of the population deteriorate (Libanova, 2018), the health care system degrades (Babenko et al., 2019), the quality of educational services decreases (Gontareva et al., 2019), which has a negative impact on the standard of living and leads to increased migration behavior of the population.

Instrumental basis of the mechanism is formed by methods, tools, levers. This is the most complex and multifaceted element of the mechanism. The effectiveness of its application determines the effectiveness of migration policy and the operation of the whole mechanism. 
Table 1 Methods, tools and levers of the motivational mechanism of regulation of migration behavior of the population

\begin{tabular}{|c|c|c|c|c|}
\hline \multirow[b]{2}{*}{$\begin{array}{l}\frac{n}{0} \\
\frac{0}{1} \\
\frac{1}{2} \\
\sum\end{array}$} & \multicolumn{3}{|c|}{ Main tools } & \multirow[b]{2}{*}{$\underset{\substack{D \\
S}}{\frac{1}{D}}$} \\
\hline & $\begin{array}{lrr}\begin{array}{l}\text { Focused on } \\
\text { intentions }\end{array} & \begin{array}{r}\text { migration } \\
\text { (motivation }\end{array} \\
\text { factors) } & & \\
\end{array}$ & $\begin{array}{l}\text { Focused on the practice of } \\
\text { migration }\end{array}$ & $\begin{array}{c}\text { Focused on the effects } \\
\text { of migration }\end{array}$ & \\
\hline 胥 & $\begin{array}{l}\text { The concept / strategy of } \\
\text { migration policy that } \\
\text { defines its ideology and } \\
\text { prevention in the donor / } \\
\text { migrant country / region } \\
\text { Socio-economic } \\
\text { development programs, } \\
\text { incl. jobs creation, } \\
\text { employment, etc. }\end{array}$ & $\begin{array}{lr}\text { Strategies, } & \text { remigration } \\
\text { programs } & \\
\text { Interstate r } & \text { visa } \\
\text { agreements, } & \text { simplified } \\
\text { border } & \text { crossing } \\
\text { procedures (for example, } \\
\text { agreements on small } \\
\text { border traffic) }\end{array}$ & $\begin{array}{l}\text { Strategies and } \\
\text { programs for attracting } \\
\text { migration potential }\end{array}$ & 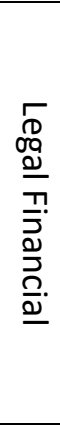 \\
\hline 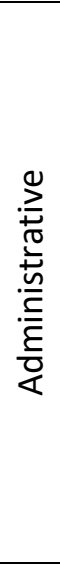 & $\begin{array}{l}\text { Standards of standard of } \\
\text { living, decent work, quality } \\
\text { of human development } \\
\text { Standards of fairness, } \\
\text { equality in population and } \\
\text { business } \\
\text { Infrastructure development } \\
\text { standards } \\
\text { Licensing of job placement } \\
\text { services, training in another } \\
\text { country / region, relocation }\end{array}$ & $\begin{array}{l}\text { Visa regime (visa and } \\
\text { customs payments) } \\
\text { Procedures for obtaining } \\
\text { legal status at a new place } \\
\text { of residence, including } \\
\text { citizenship, employment } \\
\text { permits, business } \\
\text { registration, etc. } \\
\text { Norms, standards, quotas } \\
\text { on crossing the state } \\
\text { border, obtaining legal } \\
\text { status, employment }\end{array}$ & $\begin{array}{l}\text { Liability } \\
\text { (administrative, } \\
\text { criminal) for violation of } \\
\text { norms, standards of } \\
\text { stay of a person in } \\
\text { another country }\end{array}$ & 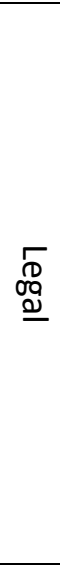 \\
\hline 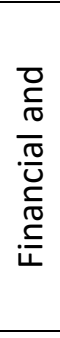 & $\begin{array}{l}\text { Decent work conditions at the } \\
\text { amount of remuneration } \\
\text { Monetary and financial stabil } \\
\text { Tax regime and social contrib } \\
\text { Business Development Condi } \\
\text { Investing in job creation and } \\
\text { donor country / region }\end{array}$ & $\begin{array}{l}\text { place of residence, incl. the } \\
\text { ty } \\
\text { utions } \\
\text { ions } \\
\text { quality improvement in the }\end{array}$ & $\begin{array}{l}\text { Preferential lending, } \\
\text { promoting the effective } \\
\text { use of migrants' income } \\
\text { upon return }\end{array}$ & $\begin{array}{l}\text { m. } \\
\text { ò } \\
\text { o } \\
\text { 3. } \\
\text { ․ }\end{array}$ \\
\hline $\begin{array}{l}\bar{\pi} \\
\overline{0} \\
\text { i }\end{array}$ & $\begin{array}{l}\text { Social protection system, } \\
\text { guarantees, in the donor cour } \\
\text { host country / region } \\
\text { Interstate agreements on } \\
\text { employment }\end{array}$ & $\begin{array}{l}\text { incl. social benefits and } \\
\text { try / region and the migrant } \\
\text { protection and mutual }\end{array}$ & $\begin{array}{l}\text { Social protection of } \\
\text { national minorities and } \\
\text { permanent population }\end{array}$ & 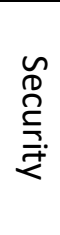 \\
\hline 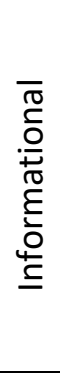 & $\begin{array}{l}\text { Formation of social unity, } d \\
\text { statehood with the support o } \\
\text { Informing about accom } \\
\text { opportunities in different cou } \\
\text { Integration and adaptation of }\end{array}$ & $\begin{array}{l}\text { evelopment of the idea of } \\
\text { f patriotism } \\
\text { nodation, work, study } \\
\text { ntries / regions } \\
\text { migrants }\end{array}$ & $\begin{array}{l}\text { Informational work } \\
\text { with the public and } \\
\text { migrants on mutual } \\
\text { tolerance } \\
\text { Diaspora } \\
\text { communications } \\
\text { Reintegration } \\
\text { returnees }\end{array}$ & 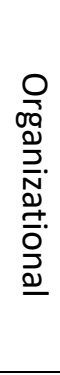 \\
\hline
\end{tabular}

Source: summarized by the authors.

The peculiarity of regulation of motivational behavior of the population is the importance of methods, which are based on the levers of legal, economic, financial, security and organizational character. Modern migration policy is dominated by regulatory and administrative methods. In the 
context of regulating motivational behavior with the simultaneous spread of human rights to choose their place of residence and work, active application of regulatory and administrative methods may reduce the motivation for migration in the case of an acceptable socio-economic situation in the country / region. Therefore, economic levers are becoming increasingly important. They are aimed at improving socio-economic situation in the country / region of residence. Primarily, such improvements should be related to social and labor spheres, reflecting the level of remuneration and welfare levels of the population. The sustainability of such phenomena in addition to infrastructure development, improvement of the political environment will ensure the quality of human development and significantly reduce the motivation of the population to migrate.

Methods, tools and levers as fundamental elements of an instrumental block of a motivational mechanism for regulating population migration behavior are summarized (table 1).

The tools are divided into three groups:

1) tools aimed at regulating the intentions of migration, i.e. the formation of migration motives;

2) migration-oriented tools, including departure and return;

3 ) tools that focus on the consequences of migration with the quality of human development.

The specificity of the instruments of regulation migration behavior of the population depends on the motives of migration under the terms of human habitat and the nature (concept) of migration policy of both the donor country and the host country. Based on current trends in the formation of global migration space (global labor market, global education system, etc.), a very strong influence on the migration behavior of the population has a difference in the level of socio-economic development between countries. Because of this, the primary task of the state in regulating migration at the stage of forming the intentions of departure of the population should be to improve the economic environment. However, the value of economic factors should not be exceeded.

According to E. Libanova (Libanova, 2018), we should pay attention to Poland, which is not only the center of gravity for Ukrainian workers, but also a recognized leader of Eastern Europe in terms of pace and quality of reforms, in terms of economic development in general. In spite of all this, despite the satisfaction of the Poles with their authority, standard of living and the situation in the country, most of them head for more developed EU countries in search of better work, higher incomes and a better life.

Thus, the formation of a global migration space with different levels of development of countries has an increasing influence on migration behavior of the population. Under such terms, the importance of forming social unity, developing the idea of statehood and supporting patriotism increases. Although the factor of personal patriotic attitudes is weakened under satisfactory welfare conditions, it does allow working out social unity beyond the borders, while maintaining close ties with representatives of the diaspora.

The application of methods, instruments and levers of motivational mechanism of regulation of migration behavior of the population through the mediation of the authorities and market institutions requires information, logistical and financial support. Of particular importance is information support, which is formed based on data, phenomena and processes that are the objects of influence (intentions, practices and consequences of migration), as well as data on the subjects of influence, which determines the effectiveness of the mechanism. Impact data should reflect quantitative and qualitative indicators of rulemaking and other management decisions, analysis of budget expenditures on migration regulation, and improvement of the environment for shaping migration behavior of the population.

Data on phenomena and processes related to migration behavior of the population should contain detailed information, the analysis of which would determine the effectiveness of regulation and the priority directions for its improvement. Improvement of information support for the motivational mechanism of regulation of migration behavior of the population is relevant for Ukraine (Podgorna et al., 2020). In Ukraine migration statistics is limited, subjective (linking the registration of migrants - 
displaced persons to registration at the place of residence under the conditions where citizens do not always register a change of residence, leads to a significant shortage of displacements) and requires unification with other countries (Reshetova, 2014).

The above-mentioned elements of the motivational mechanism of regulation of migration behavior of the population allow carrying out its schematic representation (Fig. 1).

Figure 1. Motivational mechanism of regulation of migration behavior of the population

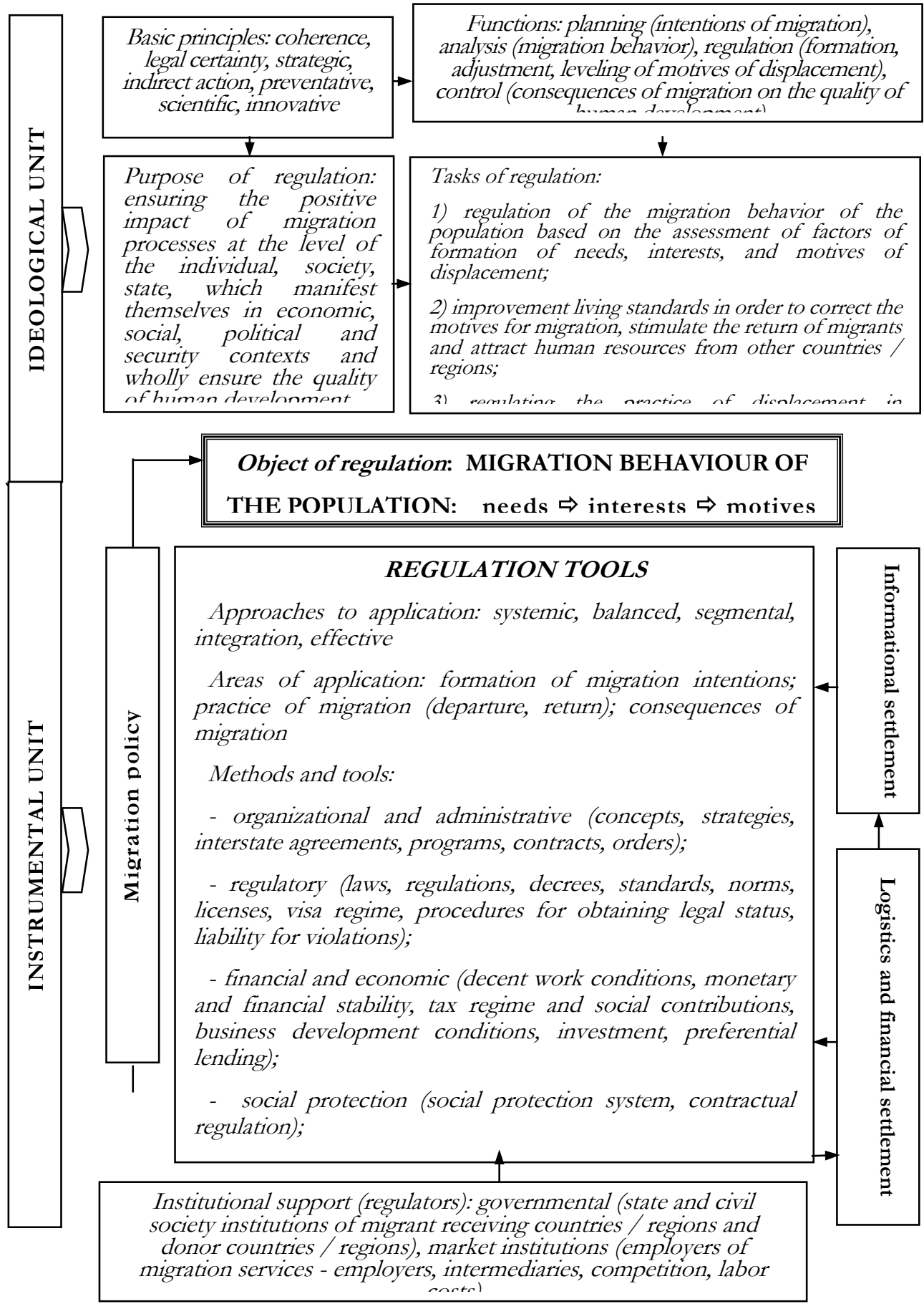

Source: Developed by the authors

It reveals its systemic character, which is accompanied by the process of interaction and complementation of various elements. 
The effectiveness of motivational mechanism depends on the functionality of its institutional support. Although experts are generally responsible for ineffective migration policies for governmental institutions, their activities depend on the proactive influence of civil society institutions.

In strengthening economic levers of influence on state structures, trade union organizations should play a key role in upholding the rights of the employed population and making its legal consciousness. In addition, various levers of influence can be used by POs as an association of migrants and institutions that provide social services for them. It is civil society, a large part of which is migrant active (marked by migration behavior), to exert pressure on the authorities to protect their needs and interests on the basis of preserving citizenship regardless of the country of residence.

The subjects of regulation depend on material, technical, financial and informational support of the motivation mechanism. In order to do this, authorities should clearly justify the benefits of the mechanism, which is regulated by migration behavior of the population. Behavioral aspects are the latest trend in regulation based on the ideas of behavioral economics (Bertrand, Mullainathan, Shafir, 2004).

Therefore, the regulation of migration behavior, taking into account the motives of movement of the individual is a modern concept of migration policy, which makes it possible to transform the spontaneous behavior of the population into a managed migration process.

\section{Discussion}

General scientific and methodological approaches of improving the motivational mechanism of regulating the migration behavior of the population outline a wide range of problems in this field. Regulatory priorities may differ for different countries / regions. However, within the national space, the conceptual foundations of regulating the migration behavior of the population should be identified with the interests of the state, society and human being harmonized.

For Ukrainian society, the motivational mechanism for regulating the migration behavior of the population has a specificity inherent in countries with transitional conditions of development that are in the competitive space of the interstate movement of resources - human, financial, information. The specificity of regulation is due to the following behavioral characteristics of the population:

1) high motivations for migration abroad for employment, study with the intention of moving to a permanent place of residence under worse working conditions in Ukraine compared to neighboring European countries, lack of stability and confidence in tomorrow;

2) growing motives of migration abroad due to the influence of powerful migration networks resulting from the constant displacement of the migratory active population and attracting an increasing number of them;

3) current motives for return (short-term migration predominance) with inefficient use of migrants' monetary income (meeting consumer needs);

4) Forming motives for family reunification, birth of children in the host country.

In this regard, the effect of the motivation mechanism should be different in changing the migration behavior of the Ukrainian population by influencing economic, social, political, military motives (Table 2).

The nature of regulation of migration behavior should include: demotivation - weakening of influence of motives; motivation - increasing the influence of motives; remotivation - re-formation, strengthening of influence of motives.

Particular attention should be paid to the issue of remotivation regarding to the economic motive for income generation and welfare. 
Table 2. The nature of regulation of migration behavior of the population: priorities for Ukrainian society

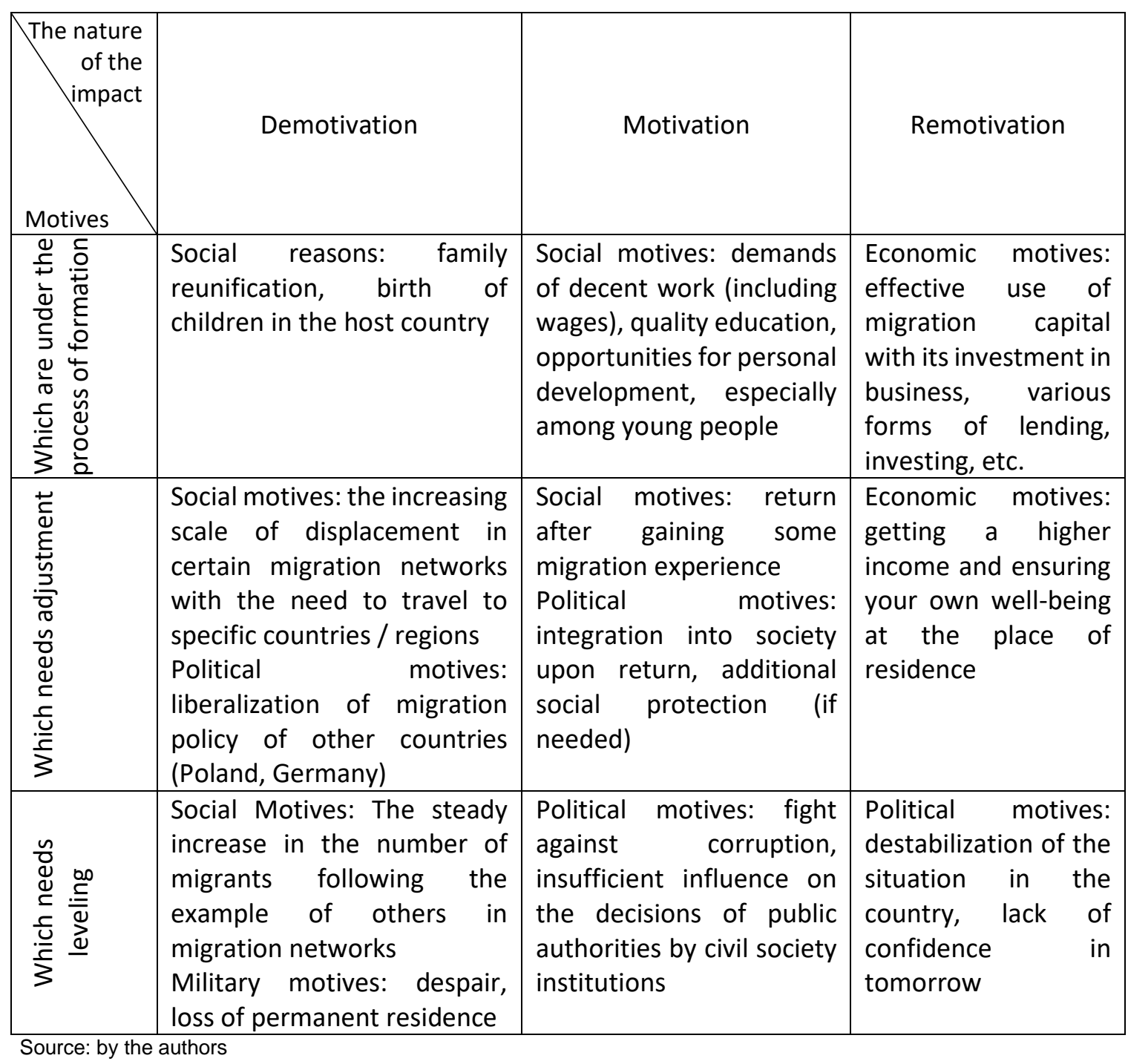

\section{Conclusion}

For a large part of the population of Ukraine, the practice of migration has become so acceptable that having a place of work and being able to obtain a certain level of income at the place of permanent residence does not always suit to a person.

Therefore, additional motivational influences on the population regarding the benefits of employment in their home region are needed. Relevant advertising campaigns are spread in Ukraine today, and billboards for domestic employers are even located in other countries where many Ukrainians are employed. It is causing labor shortages in the national labor market, especially in the border regions and in particular occupational groups.

In the unit of motivation table. 2 political motives that need correction are highlighted. It outlines the liberalization of migration policies of other countries in the context of global competition for human resources. This is a very strong factor in the migration behavior of the Ukrainian population, including those who are already abroad. Most initiatives to improve the conditions of the labor market, business development, etc. within Ukraine, it may not have the expected effect if the authorities of other more developed countries stimulate immigration in order to solve their labor shortages and demographic problems. This is confirmed by the current situation regarding to the liberalization of Germany's migration policy, much of which Poland will lose - not only because of the continued 
migration of Poles, but also because of the departure of Ukrainians to Germany as a country with higher wages (Pravda, 2018).

Regulation of the migration behavior of the population of Ukraine with a certain character (motivation, demotivation, remotivation) requires the selection of appropriate methods and tools. The main tools for regulating the migration behavior of the population, based on the results of the analysis presented in unit 2 and the need to improve decent working conditions, ensure the quality of human development in Ukraine:

on shaping migration intentions: improving the competitive conditions of the Ukrainian labor market through the application of a financial and economic wage regulator, namely its size and the deduction of payments;

on the practice (departure, return) of migration: social protection of migrants through the application of a legislative regulator to conclude interstate agreements and to monitor compliance with their provisions;

on the effects of displacement: promoting the effective use of migrants 'monetary income through regulatory and regulatory programs - re-emigration programs, and financial and economic (tax, investment, credit) regulators - supporting former migrants' businesses and their employment.

\section{References}

1. Alghamdi, A., \& Shetty, S. (2016, August). Survey toward a smart campus using the internet of things. In 2016 IEEE 4th international conference on future internet of things and cloud (FiCloud) (pp. 235-239). IEEE.

2. Bil M.M., 2017. Retrospective review of spatial mobility of the population. Demography and the social economy $1,66-78$.

3. Grishnova O.A., 2017. Integration of the Ukrainian Labor Market with the European: Threats and Prospects (evaluation on the example of the countries of Eastern Europe). Demography and the social economy 3, 162-173. Available at: http://nbuv.gov.ua/UJRN/dse_2017_3_15.

4. Kolot A.M., S.O., 2014. Tsymbalyuk Motivational management. Kyiv: KNEU, 479.

5. Libanova E.M. (2018) External labor migration of Ukrainians: scale, causes, consequences. Demography and Social Economy, 3(34), 11-26.

6. Malinovskaya O.A., 2018. Migration Policy: A Global Context and Ukrainian Realities. Kyiv: NISD, 472.

7. Malinovskaya O.A., 2011. Labor migration: social consequences and ways of regulation: analyte. ext. Kyiv: NISD, 40.

8. Petrova I.L., 2012. Labor market. Social implications of Ukraine's European integration. The Friedrich Ebert Foundation. Available at: http://library.fes.de/pdffiles/bueros/ukraine/09447.pdf.

9. Rinzak O.T., 2016. Mechanisms of regulation of population migration in the European Union. Eastern Europe: economy, business, management 4, 312-317. Available at: http://www.easterneurope-ebm.in.ua/index.php/4-2016-ukr.

10.Rinzak O.T., 2018. Factors and motives of external migration of the Ukrainian population. Socioeconomic problems and the state 1(18), 112-121. Available at: http://sepd.tntu.edu.ua/images/stories/pdf/2018/18rotmnu.pdf.

11.Sarioglo V.G., 2019. External labor migration in Ukraine: motives, scales, consequences. Science Works Journal "Ekonomichnyy analiz" 1, 36-44.

12.Tindik N.P., 2009. Labor migration in the age of globalization: integration into the world or escape from poverty: monograph. State University of Internal Affairs, Lviv, 600.

13.Ostapenko M., 2010. Ideological pluralism: the problem of the need to develop and preserve the integrity of a democratic society. Contemporary Ukrainian Politics. Politicians and political scientists about her 21, 8-23.

14. Haisal M.L., 2018. The Role of the State in the Management of Migration Processes. Investments: Practice and Experience 12, 116-119. 
15.Babenko, V., Gaponova, E., Nehrey, M., Ryzhikova, N., Zaporozhets, E. (2019). Life Expectancy of Population of the Country: the Role of Health Services Effectiveness. Research in World Economy, Vol. 10, No. 4 (Special Issue), pp. 86-91. doi:https://doi.org/10.5430/rwe.v10n4p86 .

16.Gontareva, I., Maryna, B., Babenko, V., Perevozova, I., Mokhnenko, A. (2019). Identification of efficiency factors for control over information and communication provision of sustainable development in higher education institutions. WSEAS Transactions on Environment and Development. Vol. 15, pp. 593-604.

17.Reshetova G.I., 2014. The essence of the categories "labor migration" and "migration movement of the population". Global and national problems of economy 2, 999-1003.

18.Shaikh, A. (2020). Guest Editorial: Impact of Integrated Intelligent Information and Analytical Systems on Society. Journal of Information Technology Management, 12(3), 1-3. doi: 10.22059/jitm.2020.76287

19.Podgorna, I., Babenko, V., Honcharenko, N., Sáez-Fernández, F. J., Fernández, J. A. S., Yakubovskiy, S., 2020. Modelling and Analysis of Socio-Economic Development of the European Union Countries through DP2 Method. WSEAS Transactions on Business and Economics, Volume 17, 2020, Art. \#44, pp. 454-466. doi: https://doi.org/10.37394/23207.2020.17.44

20.Marianne Bertrand, Sendhil Mullainathan, Eldar Shafir, 2004. Behavioral-Economics View of Poverty. American Economic Review 94(2), 419-423.

21. Most Ukrainians in Poland are ready to move to Germany if they open the labor market: Ukrainian Truth. Available at: https://www.pravda.com.ua/news/2018/08/2/7188110/.. 